
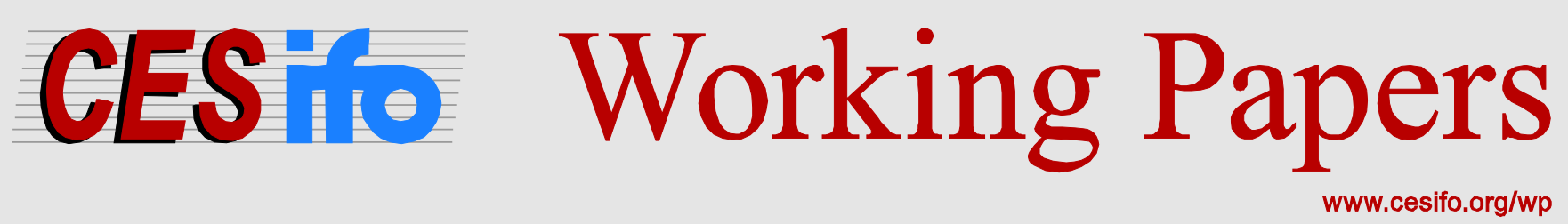

\title{
Land, Men, Taxation An Application to Pre-Modern China and Europe Erik Jones’ European Miracle Revisited
}

\author{
Charles B. Blankart
}

CESIFO WORKING PAPER NO. 4936

CATEgory 1: Public Finance

August 2014

An electronic version of the paper may be downloaded

- from the SSRN website:

- from the RePEc website:

- from the CESifo website:

wWw.SSRN.com

Www.RePEc.org

www.CESifo-group.org/wp

\section{CESifo}




\title{
Land, Men, Taxation An Application to Pre-Modern China and Europe Erik Jones’ European Miracle Revisited
}

\begin{abstract}
Eric Jones has found that excessive taxes were detrimental for pre-modern China's economic growth whereas moderate taxes were conducive for Europe's economic growth. This paper provides a political-economic answer to the question why these two tax systems came about. Taxation is only feasible when men and land can be linked as a single bundle. Taxation of land is not feasible without men, and taxation of men is not feasible without land. A tax maximizing bureaucrat has to combine the two variables in such a way that tax revenues are maximized given the constraints of land and men in his country. China's contiguous geography allows bureaucrats to establish an autocratic tax system whereas Europe's split geography enforces a competitive tax system. Therefore often contiguous states reveal to be stable states whereas split states turn out to be unstable and prone to collapse.
\end{abstract}

JEL-Code: H200, N400, P500.

Keywords: land, population, taxation, autocracy, multipower system, Great Divergence debate.

\author{
Charles B. Blankart \\ Humboldt-University Berlin \\ Tristanstr. $17 \mathrm{D}$ \\ Germany - 14109 Berlin \\ charles@blankart.net
}

PR 21 July 2014 
The golden age was first; when Man yet new,

No rule but uncorrupted reason knew: And, with a native bent, did good pursue. Unforc'd by punishment, un-aw'd by fear, His words were simple, and his soul sincere;

Ovidius Metamorphoses (first book)

11 April 2014

\section{Land, Men and Taxation}

\section{An Application to pre-modern China and Europe \\ Erik Jones' European Miracle Revisited ${ }^{1}$}

by

Charles B. Blankart

Humboldt-University Berlin

University of Lucerne

CESifo, CREMA

\section{Explaining the Great Divergence}

The Great Divergence is the phenomenon that shows that Asias's economic growth lagged behind Europe's economic growth for many hundred years, and indeed, until only recently. Max Weber (1923), Kenneth Pomeranz (2000), David Landes (1998) and other renowned scholars have tried to understand this puzzle. They point to the economic sources of growth, such as capitalism, the availability of resources and technologies, to explain the economic lead of Europe over Asia. Eric Jones, however, has taken another position. In his book The European Miracle" $(1981,1987,2003)$ he discusses the economic variables as well, but he argues for considering first of all the political sources of economic growth that are rooted in the organization of the State. The State determines economic growth because it has command over the rule of law, over property rights, over trade and taxation, which all determine indirectly the rate of growth of an economy.

When Jones refers to Asia he mostly means China while leaving India and South-East Asia aside. We shall follow Jones in this regard because China is a well-defined entity and therefore easier to discuss

\footnotetext{
${ }^{1}$ The author is indebted to Geoffrey Brennan, Peter Bernholz and to an anonymous referee for helpful comments as well as to Mats Geiden von Schwarzenburg for editorial support.
} 
compared to the rest of Asia. But much of what can be said about China is also applicable to the other countries and will be summarized when appropriate.

We characterize China as a "contiguous" country because it is situated in a large contiguous Continent. Europe is "split" in the sense of being "non-contiguous". It is more than simply "divided" and less than "fissured".

According to Jones' argument, the agents of the state in traditional China wanted to maximize tax revenues. Therefore, taxed individuals had little incentives to invest. Per capita income remained low, and Chinese growth lagged behind growth in Europe where taxes were less exploitative and the rate of growth was higher. These institutional differences prevented a convergence of the rates of growth of China and of Europe. Jones writes: "Peasants were without redress against arbitrary taxes [in China] to the point that eating any small surplus that the harvest did provide made more sense to them than hazarding in new ventures" (p. xxx). Europe, in contrast, had more of a rule of law protecting its peasants from a sovereign's caprice of taxation. Therefore we observe higher growth rates in Europe than in Asia.

The factors determining taxation will be discussed in this paper, which is divided in four sections. Section II provides a comparative theory of the history of taxation in China and in Europe, and an illustrative breakdown with calibrated data is given in section III. Section IV summarizes what philosophers of the Enlightenment thought about taxation in Europe and in Asia. Section V provides further statistical evidence while Section VI is devoted to conclusions and generalizations.

\section{A Theory of Taxation Based on Land and Population}

Jones describes taxation as autocratic in China and competitive in Europe. But why was taxation different in China from taxation in Europe? Most scholars point to history: they argue that the present taxation can only be understood from the taxation in the past. Some countries have an authoritarian tax system because such a system has been inherited from their history. But relying on history has a great disadvantage. History follows a given time path: the French Revolution cannot be placed before the thirty years' war, and Henry VIII of England cannot reign before Charlemagne, etc. But even after having established the right sequence of events, it does not become clear which event is the decisive one. What was most important for Europe: the French Revolution, Henri VIII, the Thirty years' war or Charlemagne? To simply to begin somewhere is not convincing as the economist Paul David (1985) correctly reminds us: "important influences upon the eventual outcome can be exerted by temporally remote events." Eric Jones seems to be aware of this problem. In his book on The European Miracle, he therefore traces European history back link by link up to the Mesolithic past (p. 11). But was the Mesolithic past really relevant? What was relevant in the Mesolithic past and why? What was before the Mesolithic past? Was the anterior history possibly relevant? Nobody knows. The conclusion is that history is not a good guide to understand the present. When using the past, a historian inevitably struggles in the trap of an infinite regress: whatever event is declared as the "first event", it is inevitably an arbitrarily chosen event. Jones makes no exception and he cannot escape this trap. If history is to be understood, an exogenous variable outside it is needed to explain that history. 
The governments of historical China had obviously more power to tax than the governments in past Europe. But where does this power come from? Taxation always comes from the interaction of land and individuals. Land alone is neutral. It cannot be taxed as long as individuals are absent for only individuals can be taxed. On the other hand individuals per se cannot be taxed either. A government cannot get hold of individuals who cannot be tied to land at least for some time. A bureaucrat is a good tax agent if he is able to link individuals to land in such way that taxes are maximized. What specific tax is raised is a secondary problem within his task because a tax is always capitalized in land values when individuals are mobile: eventually every tax is a land tax.

In the early times of hunters and gatherers, individuals could hardly be taxed. Landowners may have had plenty of land, but in addition there was a large amount of unoccupied land, which allowed individuals to escape from taxation. Without taxation the economy grew at a high rate as is recorded from China (see section III). Gradually, however, land was filled up by individuals, and became scarce. What could the individuals do? In a contiguous territory such as China individuals found it difficult to escape from taxation by settling outside proprietary land. The relationship between land and individuals has turned to the disadvantage of individuals. Land owners established themselves as governments who were able to impose taxes from which individuals could not escape. This became possible because the scarcity of land increased under the growing size of the population. Proprietary land could no longer be avoided by individuals who wanted to settle. Each landowner became able to tax the settlers according to the scarcity of his land, and as the scarcities differed among lots of land, land owners could exploit settlers at different rates. But land owners could make even more money if they merged and taxed the individuals according to the price elasticity of demand for each lot.

Therefore, once land had become a source of taxation, landowners had a strong incentive to merge into one large tax district leading eventually to the unification of a country such as China (see section III).

If this theory is correct, its logic has to hold for any country and for Europe as well. But Europe's geography is different leading to a different form of taxation. Europe is not only much smaller than China, its territory is also split in many islands and peninsulas. Increasing the domain of land required higher costs in Europe than in China. In contiguous China increasing a circular domain required constant costs ( $c \times 2 \pi r$ ) while the surface of the territory (and the number of subjects) increased at the second $\left(\mathrm{c} x \pi \mathrm{r}^{2}\right)$. In Europe, however, the costs of increasing the domain were higher due to its split territory (larger than $c \times 2 \pi r$ ) while the territory increased at less than $c x \pi r^{2}$. The benefit cost ratio from extending a domain was therefore less favourable in Europe than in China. Consequently, the extension of domains remained smaller in Europe than in China, and taxation was less exploitative in Europe. Therefore, individuals invested more in Europe and GNP growth was larger in Europe than in China.

Our critics may object that China is a split continent too, and they may be right. But looking at the mere size of the two continents does make it clear that China is more like a convex body whereas Europe looks more like a skeleton. Therefore, with rising population Europe remained a multipolar power system without a consolidation of the tax bases. Individuals in Europe who felt that their taxes were too high, could emigrate into the niches of the continent situated between the sea and the mountains which are often tax free zones, and often zones where the settlement was promoted by competing governments by promising lower taxes. Therefore individuals had a greater incentive to 
invest and therefore Europe generated a higher rate of economic growth than China whose growth fell back and added to the Great Divergence.

Jones has clearly seen the different effects which are generated by single power system in China versus the multipolar system in Europe:

“The proper units for our purposes are therefore the European states' system and the great contemporary empires. ... Europe was bonded economically as much as politically. A better understanding may be gained of the total economy of the states-system by comparing and contrasting it with the other large economies of the time, organized as they were in political empires, situated in Asia or at any rate in Asia and the Middle East." (pp. xxv; xxvi). And most forcefully: "Europe as a whole might have adopted one of several political forms. ......Most of the large populations of the world were organised into empires and the empires had been growing in size for millennia .... [In Europe] after the fall of Rome no empire was successfully built..., from the time of Charlemagne to the Habsburgs and beyond. The ambitions of Charles V failed in the 1550s, the ambitions of his son Philip II failed, and the Habsburgs failed again in the Thirty Years War, when Gustavus Adolphus, subsidised by Richelieu in one of those cross-alliances that came to typify European rivalries, was able to thwart them. Europe instead became a single system of states in which change in one cell affected the others" (Jones, 2003, p. 104). "It was more important still that the number of states never shrank to one." (p. xxxvi).

Jones has a clear view of the state structures in China and in Europe. But he has not yet tried to explain the conditions favouring an autocratic state system in China and a multipolar state system in Europe. We share Jones' view, but we have to consider, in addition, the interrelationship between population, land and taxation on both continents in order to explain taxation. As long as the population density was small in the early periods of China and of Europe and land was abundant, as indicated in fields (1.) and (2.) of table 1 below, both Asia and Europe grew substantially. But as land became scarce, escape from taxation became more difficult in contiguous China (field 3.) than in split Europe as indicated in field (4.). Land and homo oeconomicus may appear in whatever combination (fields (1.), (2.) or (4.), land may be abundant or scarce, but the more land is contiguous, the larger will be the State's power to tax land plus individuals exploitatively and to stifle down the rate of economic growth as in field (3.).

Table 1: Population and the Character of Land

\begin{tabular}{|l|c|c|}
\hline Land is & abundant & scarce \\
\hline contiguous & (1.) Early China & (3.) Later China \\
\hline split & (2.) Early Europe & (4.) Later Europe \\
\hline
\end{tabular}

Source: Own compilation 


\section{Calibrated Data}

a. Early China: Let us assume a hypothetical day zero when the Eurasian sheet is opened for human beings. On this initial day there is only homo oeconomicus and land. A third resource, which is also given the first day, is climate, but let us assume that extreme zones of climate are avoided and only moderate zones are chosen for living. Land is available in unlimited quantities. Cost of an individual to increase its land is linear at $c \times 2 \pi \Delta r$ with the circumference in contiguous Asia as only invaders from outside have to be thwarted. Land owners (as homines oeconomici) can derive utility from land, but land alone provides little utility as long as it cannot be combined with command over men. The problem for landowners is therefore to obtain command over both land and men. Since men are mobile as hunters and gatherers, they must be paid their marginal product in order to settle and be induced to work on the land owners' land. Any tax beyond their costs or any pay below their marginal product induces these individuals to emigrate to unoccupied land and to return to the life of hunters and gatherers. No rent or tax can be obtained beyond costs: in equilibrium, different land owners have power over circles of land, but none of them can exert command over men. This was the Golden Age as described by Ovidius in his Metamorphoses at the outset of this paper.

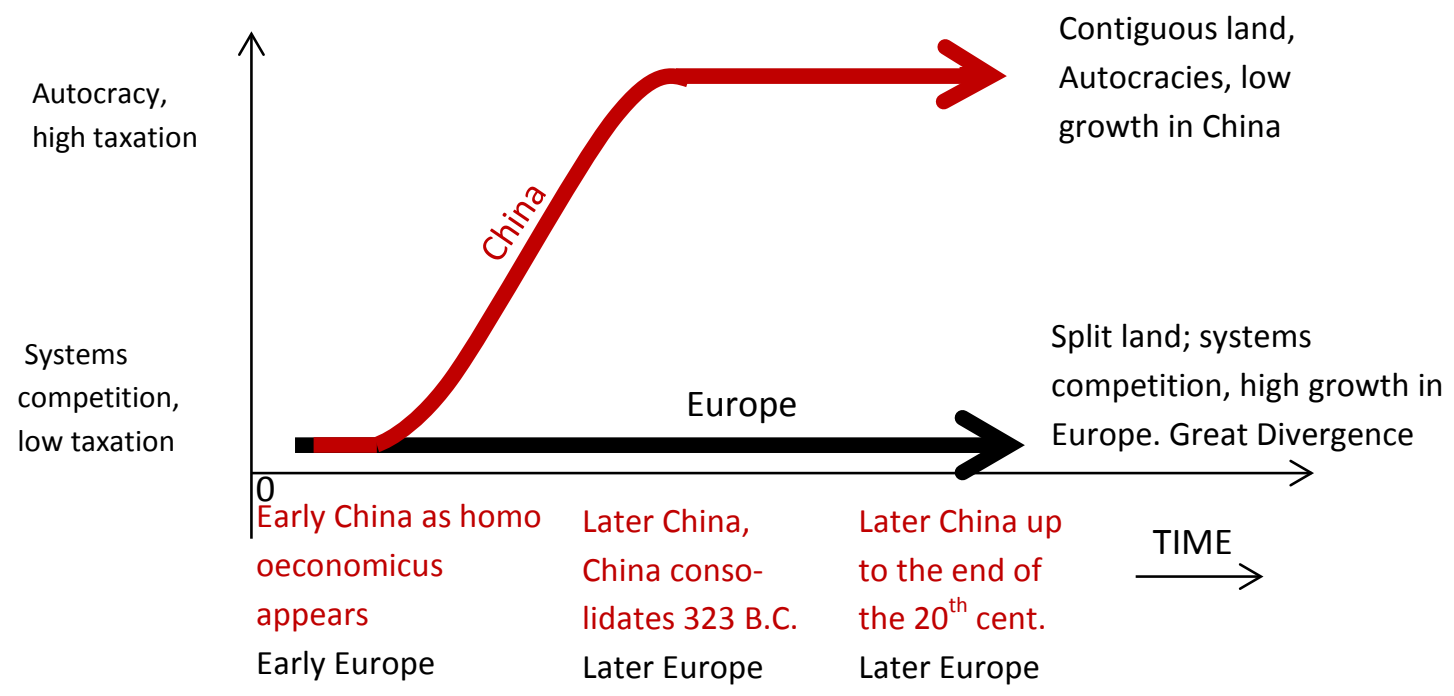

Figure 1: Autocracy and Systems competition in contiguous and in split territories

Source: Own compilation

b. Later China: In figure 1 Early China is depicted with a red arrow far left on the bottom. The rates of growth are high as there are no taxes in Early China. As soon, however, as land is filled up in Later China emigration becomes difficult and costly and land owners will charge 
settlers according to the scarcity of land. They become power holders who will tax non-land owners for settling in their land. Taxes increase according to land value, but initially remain restricted given that land owners are in competition. But land owners grasp the opportunity of increasing their tax revenues even more by mutually consolidating their tax bases.

Separate domains merge into large entities. China ceases to be a competitive power system. Its power holders consolidate politically, eventually unify and become Imperial China by 323 B.C. which never split again (see section VI). This is why China's unification has been placed in the center of figure 1. China's unification is the pivotal point between competitive and despotic China.

c. Early Europe: Early Europe does not differ much from Early China. Early Europe is depicted by the black arrow on the bottom of figure 1 . The costs of expanding command over land are presumably higher in Europe than $\mathrm{c} \times 2 \pi \Delta$ in China because Europe has a split geography. Moreover individuals are mobile in Early Europe preventing excessive taxation.

d. Later Europe differs from later China because land is not contiguous, but split. The possibilities of taxing individuals excessively are smaller in a split territory from which individuals can escape into the niches between land and sea. Moreover autonomous regional governments can emerge in a split territory and attract emigrants with lower taxes. Competitive territories are sustainable in Europe but not in China which has only provinces bound by instructions from above. Europeans have more alternatives to escape from their sovereigns' taxation and oppression than the inhabitants of contiguous Asia. Therefore, systems competition can be sustained and tax monopolies are avoided in Europe.

To put it differently: An autocratic system relying on command may work within simple structures of contiguous territories. It breaks down in a complicated geographical environment where individuals find their own ways of utility maximization.

The right hand side of figure 1 corresponds to the view which Jones and his colleagues have developed on the Great Divergence. Systems competition in Europe (black arrow) generates a higher economic growth than autocracy in Asia (red arrow). But, in addition, we provide an explanation why systems competition emerges in Europe and why autocracy dominates in China. In Asia population density is high and emigration is limited because the continent is contiguous. Therefore taxation is high and exploitative and growth rates are low. In Europe, however, migration persists and leads to competition among territories.

Remember that Asia as well as Europe started competitively. When homo oeconomicus first appeared, population density was small in China (lower part of red arrow) as it was in Europe (black arrow). Mobility in China was, therefore, high and so was economic and population growth. But the more China succeeded in economic and population growth, the more it became trapped in the limited availability of land, and hence the red arrow went upwards from competition to autocracy.

Europe, which is depicted by the black arrow on the bottom of figure 1, also had economic and population growth. But expanding domains was more costly in Europe than in China and, in addition, 
escape from taxation was easier in split Europe than in contiguous Asia. So Europe remained a competitive multistate system while Asia became dominated by a few great empires.

This is exactly what Mo observes in terms of China's antiquity when its population was still relatively small (Mo, 2004). Mo writes that a "well established feudal system was founded by the Chou dynasty in 1122 B.C." and then proceeds to state "that more than 1000 states were established by the Chou dynasty. ... The survival possibilities of the states, and hence of the autocrats, were therefore dependent on the states' relative economic and military strengths. The fierce competition among the despotic rulers forced them to design and adopt institutions favourable to economic development and hence military independence. This resulted in the most important and exceptional period in the formation of China and her culture" (Mo, 2004, p. 58). ${ }^{2}$

This prosperous period ended in the second half of the third century B.C. when China's population had grown to $27 \%$ of the world population, indeed an enormous success in economic growth under a competitive regime. It should be noted, however, that the ongoing theories of the Great Divergence cannot explain why early China had such a large population in the first millennium B.C. Our two-stage theory depicted in figure 1 is, however, able to explain both: early and later China. ${ }^{3}$

But due to this success land became scarce in China, high population density made emigration difficult within China's contiguous territory, and consequently States became increasingly powerful. They became natural monopolies whose tax power increased with their size, and mergers increased that power even further. Therefore, it is not surprising to observe cumulative state mergers in the first half of the 3rd century B.C., a process that ended with China's unification in 323 B.C. China's territorial natural monopoly was so strong that it has remained unified and never disintegrated through the present (see section VII).

It is true that an enlightening interlude of this depressing history appeared with the Sung dynasty with its open economic policy from 960 to 1275 A.D. This dynasty promoted trade and navigation based on a fleet of junks flowing over the oceans allegedly even around Africa. But progress came to a halt again under the following Ming dynasty (1368 to 1644) when the ownership and the use of large boats became a cause for capital punishment. The following dynasties pursued similar policies, with interludes, ${ }^{4}$ up to the founding of the People's Republic of China of 1949.

These theoretical considerations are again confirmed by Mo: "Apart of some relatively short periods of disintegration between dynasties, the autocrats seldom experienced long-lasting and fierce competition. ... Without effective competition, instead of enriching the states and strengthening the army, the autocrats indulged in conspicuous consumption and chose politics to extend their privileges and to ease their chances of maintaining power......which resulted in long-lasting stagnation in imperial China" (Mo, 2004, pp. 58, 59).

\footnotetext{
${ }^{2}$ The idea of competitive feudal system is also proposed by Weede (2000).

${ }^{3}$ No distinction is made between population and income per capita because the latter is not available. Feuerwerker convincingly writes on China: "No population can grow at any significant degree for any length of time without the total production of the economy increasing in some proportionate measure." (Feuerwerker 1990, p. 229).

${ }^{4}$ Growth during the Sun Yat Sen Republic of 1912 was destroyed in the civil and Japanese wars through 1950.
} 
The reader may find a graphical illustration of later Asia and later Europe in figure 2. The large circles illustrate the autocratic regimes of China and India, in particular Moghul India which was a centralized regime as well, but consider Blankart (2007) for a discussion of the Indian regimes some of which were less centralized. The small circles in the West stand for the competitive states of Europe, while the Ottoman Empire in the middle represents a mixed case. Our hypothesis on split territories is confirmed by the example of Japan in the Far East. Japan is also characterized by a broken territory and was decentralized from the fourth century up to the Tokugawa period which ended in the late 19th century (Schefold, 2001, and Distelrath, 2004).

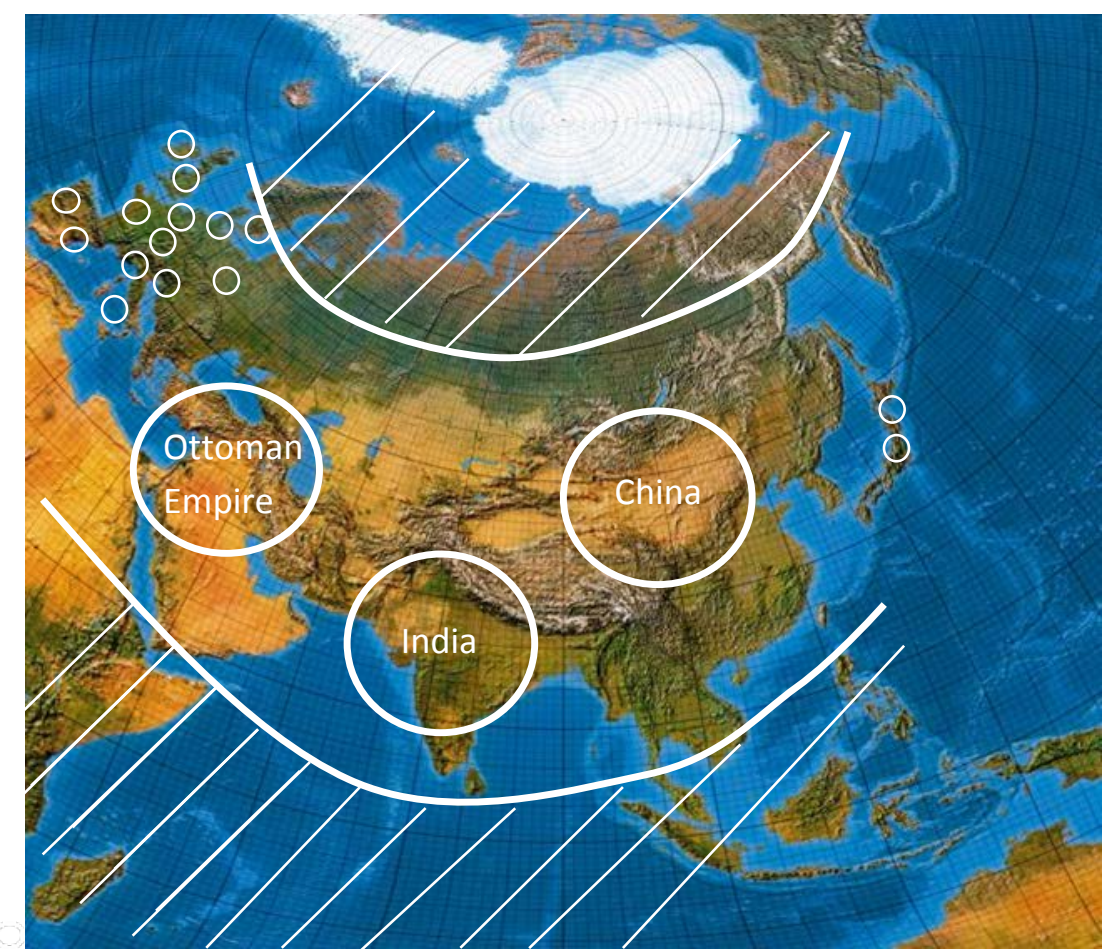

Figure 2: Natural autocracy in Asia and systems competition in Europe and in Japan

Source: Own adjustments to untraceable background source.

\section{Philosophers on Homo Oeconomicus and Land}

It is argued in this paper that taxation in a country results from the interaction of population growth and land. Some readers may be perplexed on the relevance of land, but looking back in the history of philosophical thought the use of land is not at all strange. It can be found in the works of renowned philosophers such as David Hume and Charles de Montesquieu.

The first to discover the relationship between land and government was David Hume. In his essay "Of the Rise and Progress of Arts and Sciences" 1742, he writes:

“... Europe is at present a copy at large of what Greece was formerly a pattern in miniature...If we consider the face of the globe, Europe, of all four parts of the world, is the most broken by seas, 
rivers and mountains and Greece of all countries of Europe. Hence, these regions were naturally divided into several distinct governments. And hence the sciences arose in Greece; and Europe has been hitherto the most constant habitation of them." (Hume 1742, pp. 135 and 137).

A few years later Charles de Montesquieu made a similar observation in his book « De l'esprit des lois »: (1748)

"In Asia they have always had great empires; in Europe these could never subsist. Asia has larger plains; .... and the rivers being not so large form more contracted barriers. ${ }^{5}$ Power in Asia ought, then to be always despotic; ... In Europe the natural division forms many nations of a moderate extent, in which the ruling by laws is not incompatible with the maintenance of the State; in the contrary; it is so favourable to it that without this the state would fall into decay and become a prey of its neighbours. This is which has formed the genius of liberty." (Montequieu $174817^{\text {th }}$ book, Ch. 6).

Hume and Montesquieu found that it is not just by accident that large contiguous countries tend to become autocracies, while geographically split countries often have decentralized competitive governments.

\section{Statistical Records}

\section{a. Geniuses: by Alfred Kroeber and Charles Murray}

The Hume-Montesquieu hypothesis of systems competition and growth has been summarized by the German-American scholar Alfred Kroeber (1944) who succeeded in providing a first statistical account of the inventive capacity of the world. Kroeber searched through all available encyclopedias of the world and counted the number of geniuses including those in visual and performing arts since antiquity. He found that the West had two thirds of all geniuses, but only one fourth of the population, whereas the East (without Japan) had one third of the geniuses and artists, but three fourth of the population (table 2).

Table 2: Geniuses in Arts and Sciences 500 B.C. until 1899 A.C.

\begin{tabular}{|c|c|c|c|c|}
\hline & $\begin{array}{c}\text { Geniuses, } \\
\text { thinkers and artists } \\
\text { from 500 B.C. to the } \\
\text { end of the 19.century }\end{array}$ & percent & $\begin{array}{c}\text { Population around 1500 } \\
\text { A.D. in } \\
\text { in million }\end{array}$ & percent \\
\hline $\begin{array}{c}\text { Europe und } \\
\text { Western } \\
\text { descendants }\end{array}$ & 626 & 64 & 90,518 & 25 \\
\hline China & 175 & 18 & 103,000 & 29 \\
\hline India & 51 & 5 & 110,000 & 31 \\
\hline Middle East & 123 & 13 & 55,400 & 15 \\
\hline
\end{tabular}

5 "contracted" or man-made rather than natural. 


\begin{tabular}{|c|c|c|c|c|}
\hline TOTAL & 975 & 100 & 358,918 & 100 \\
\hline
\end{tabular}

million inhabitants.

Sources: Own compilation based on Kroeber (1944), and Narrol u.a. (1971), Population from A. Maddison (2003).

Kroeber's impressive data have been criticized for being Eurocentric. Therefore, Charles Murray (2003) has reviewed and summarized Kroeber's work fifty years later by counting human accomplishments since antiquity but now doing so with the help of computers. His list encompasses 4.002 excellent personalities in natural science, philosophy, visible art, literature and music in Europe, in the rest of the West and everywhere else between 800 B.C. and 1950 A.C. Figure 3 shows that the majority of all genial accomplishments have been generated since the $15^{\text {th }}$ century, especially since the $19^{\text {th }}$ century. What is most surprising is that the number of geniuses in Murray's work is even more Eurocentric than in Kroeber's record. As late as 1880, 81 percent of the new geniuses came from Europe, thereafter Europe's share dropped, but was still about 60 percent in the 1940s. Nowadays the number of geniuses increases faster in the "Rest of the West", especially in the U.S.

In order to avoid the criticism of a European bias, Murray counted the artists in China, in India and in Japan separately whereas he aggregated them over all European states. But as can be seen from figure 3, Europe still ranges first in the sample.

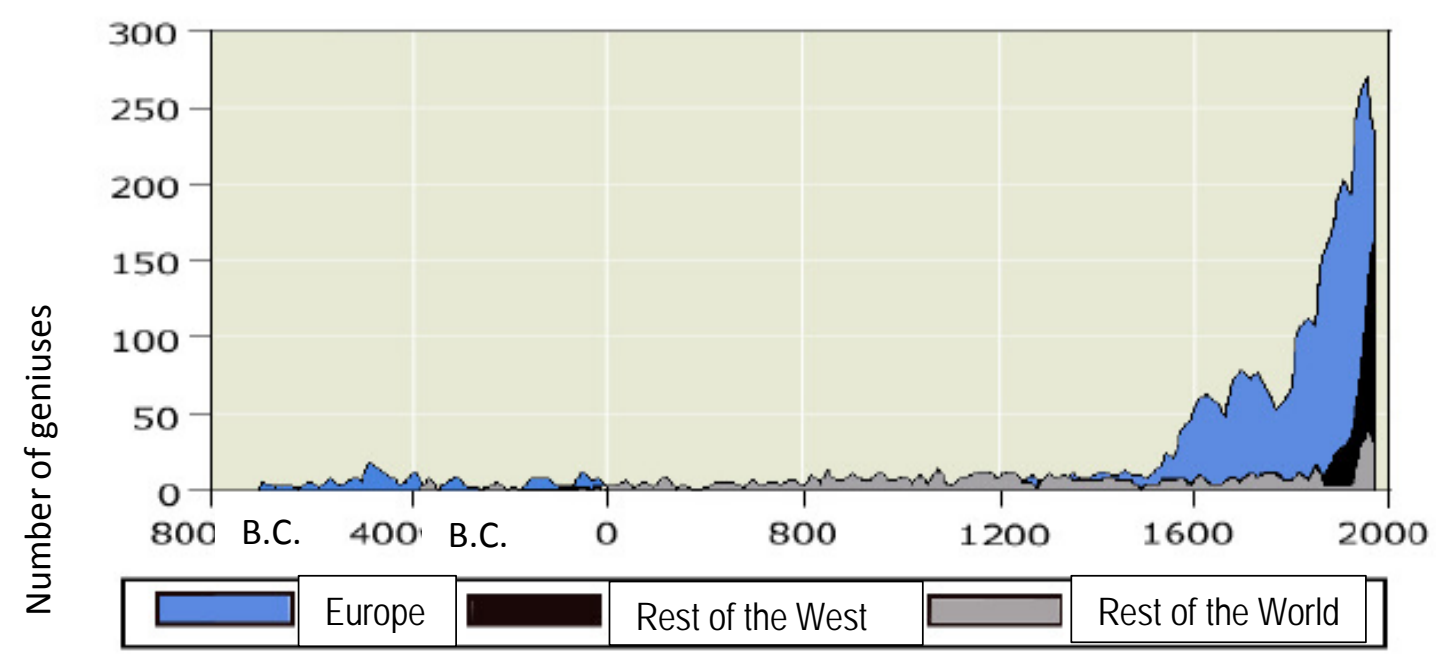

Figure 3: Geniuses in the world

Source: Own compilation based on Charles Murray (2003) 
Another Western prejudice could come from Murray's additive method of counting inventories. If a large number of single accomplishments such as the wheel, the plow, the stirrup, the gun powder, the eyeglasses and the mechanical clock are simply added up it cannot be excluded that some of them had already been known in very early centuries in Asia and therefore receive too much weight in Murray's accounts. This danger is reduced if not single but rather meta-inventions are counted, i.e. those that generated secondary inventions. Murray defines 14 such meta-inventions in his work and then looks back to the origins where they come from. Indeed some of them come from outside Europe such the Arabic numerals including the number zero: they may have been invented by Indian-Arab mathematicians at the end of the 8th century A.D. Similarly, meditation appeared in India around 200 B.C. and ethics coming from China (and from Greece) may be assessed at around 500 to 300 B.C. But most meta-inventions quoted by Murray originate from Europe, particularly those from philosophy and mathematics, among which the logic of the mathematical proof and the treatment of uncertainty, nature as an object of observation and the scientific methodology are the most important. Similarly, meta-inventions in arts: Realism, the perspective abstract art, polyphony, drama and the novel seem to be of European origin.

\section{b. Angus Maddison: Comparative Economic Growth}

The Great Divergence in GDP per capita is demonstrated impressively in the statistical record by Angus Maddison (2003 on table 3). Following his data, all regions of the World including China started with the same GDP per capita of about 400 US $\$$ around the year 1 A.D. Europe's GDP shrunk during the first period from year 1 to year 1000 from 450 to 400 US\$ per capita due to the collapse of the Roman Empire and the following migration period. But it resumed substantially after 1500 from 771 US\$ per capita to 4579 US\$ per capita in 1950 and reached 19912 US\$ per capita in 2003. The greatest lead of Europe over China was 10:1 in 1950, it then declined to 4:1 in 2003. The West European Offshoots in the New Worlds were even more remarkable: they attained 28039 US\$ per capita or 6:1 in 2003.

Table 3: Economic Growth in Asia and in the West from year 1 to 2003

\begin{tabular}{lccccc}
\hline \multicolumn{5}{c}{ Real GNP per capita } \\
& \multicolumn{5}{c}{} \\
\hline China & 1 & 1000 & 1500 & 1950 & 2003 \\
Japan & 450 & 450 & 600 & 439 & 4803 \\
India & 400 & 425 & 500 & 1921 & 21218 \\
W'Europe & 450 & 450 & 550 & 619 & 2160 \\
W'European & 450 & 400 & 771 & 4579 & 19912 \\
Offshoots & 400 & 400 & 400 & 9268 & 28039 \\
World & 445 & 436 & 566 & 2111 & 6516 \\
\hline
\end{tabular}

Source: OECD Data

Own compilation

\footnotetext{
${ }^{6}$ Estimates of Roman GDP (PPP) per capita (see Maddison 2003).
} 


\section{Conclusions and Generalization}

Eric Jones correctly observes that

- Traditional China had excessive taxes and low economic growth

- Traditional Europe had lower taxes and higher economic growth.

A simple answer is to say that China had an autocratic tax system and Europe a competitive tax system. But this answer does not explain why China's tax system was autocratic and why Europe's tax system is competitive? We therefore have to ask what a bureaucrat has to consider if he wants to maximize tax revenues in pre-modern China or in Europe respectively.

A bureaucrats' problem is to join land and individuals for taxation. For land cannot be taxed without individuals and individuals cannot be taxed without land. In an archaic territory where land is abundant and population small or absent, taxation is not feasible. Hunter-gatherers will simply withdraw from landowners' land making taxation impossible in China as well as in Europe.

Taxation becomes feasible when population grows into a geographically contiguous territory which is gradually filled by individuals who now can be tied to the land and taxed. We believe that contiguity holds approximately for continental China. If land is, however, not contiguous, but split as in Europe, the extension of a dominion is costly allowing, on the one hand, taxpayers to escape from taxation and, on the other hand, rival governments to establish power in remote areas. Contiguity of land allows an understanding why an authoritarian tax system can be established in China and remain stable there despite of its presumed inefficiency for growth. In Europe, whose territory is split, governments are in permanent competition and an authoritarian tax system is not feasible. The political economy of contiguous versus split domains may explain the phenomenon of The Great Divergence between Europe and China.

We believe that our theory has a broader application: it can explain to some extent the stability and instability of political regimes in general.

The example of China has shown that contiguous territories join to non-competitive entities and may become stable non-contested nations that remain stable and seldom disappear. China, Russia, the United States, the united Germany (1871) and South Africa are examples.

Split territories remain competitive and contestable and are, as such, always unstable and prone to dissolution. Examples are the later Roman Empire, the Colonial Empires of Europe, the two Pakistans, the former United Arab Republic (of Egypt and Syria) and the European Union.

We concede that not all countries can be encompassed by our theory. Deviant cases are Indonesia, the Philippines and former Yugoslavia, but nevertheless, we believe that the nature of split versus contiguous geographies can contribute to a better understanding of the stability or instability of nations. 


\section{Literature}

Blankart. Ch. B. (2007), Föderalismus in Deutschland und in Europa, Baden-Baden: Nomos)

Clayton E. (2005), Aristotle: Politics, in: Internet Ecyclopedia of Philosophy http://www.iep.utm.edu/aris-pol/ (24 March 2014)

Colin M., and Richard Jones, Atlas of World Population History (Penguin, 1978)

David, P.A. (1985), Clio and the Economics of QWERTY, American Economic Review, Vol. 75, No. 2, P\&P, pp. 332-337.

Distelrath, G. (2004) Advantages of centralized and decentralized rule in Japan, in: P. Bernholz and R. Vaubel, eds., Political Competition, Innovation and Growth in History of Asian Civilizations, Cheltenham: Elgar: 96-112.

Hume, D. (1788), Of the Rise and Progress of Arts and Sciences, in: David Hume: Essays and Treatises on several subjects, Essay Nr. 14, London first published 1742.

Huntington, S. (1996), The Clash of Civilizations and the Remaking of World Order. Simon \& Schuster, New York.

Jones E. (2003), The European Miracle, Cambridge: Cambridge U. Press 1981, 1987, $2003^{3}$.

Kroeber, A.L. (1944) Configurations of Culture Growth, Berkeley und Los Angeles (University of California Press).

Landes, David S. (1998). The Wealth and Poverty of Nations: Why Some Are So Rich and Some So Poor. New York: W.W. Norton

Maddisson, A. (2003) The World Economy: Historical Statistics, Paris: OECD

Mo, P.H. (2004), Lessons from the History of Imperial China, in: P. Bernholz and R. Vaubel, eds., Political Competition, Innovation and Growth in History of Asian Civilizations, Cheltenham: Elgar: 5774.

Montesquieu, Baron de la Brède et de Montesquieu, Charles Louis de Secondat (1748), De L'Esprit des Lois, Genève (Barillot). Engl. : The Siprit of Laws (Lonang Library PDF)

Narrol, B., E.C.Benjamin, F.K. Fohl, M.J. Fried, R.E. Hildreth und J.M. Schaefer (1975), Creativity: A Cross Historical Pilot survey, Journal of Cross-Cultural Psychology, Vol. 2, S. 181-188.

Pomeranz, K. (2000), The Great Divergence: China, Europe, and the Making of the Modern World Economy, Princeton, NJ, Princeton University Press.

Schefold, B. (2001), Ein Leitbild für die Tokugawa-Zeit: Miura Baiens 'Kagen', in: Vademecum zu einem japanischen Klassiker des ökonomischen Denkens. Kommentarband zum Faksimile-Nachdruck 
der zwischen 1773 und 1789 entstandenen Handschrift Baien, Miura: Kagen, Klassiker der Nationalökonomie, Düsseldorf: Verlag Wirtschaft und Finanzen, pp. 5-33

Volckart, O. (2002), Wettbewerb und Wettbewerbsbeschränkung im vormodernen Deutschland. 1000-1800, Tübingen (Mohr) 2002.

Vaubel, R. (2012), Freiheit in Deutschland: Wettbewerb der Staaten, Einfluss der Kirche, am V.2 Endogenous technical progress.

Weber, M. (1923), Wirtschaftsgeschichte, Berlin: Duncker und Humblot. 